\title{
Reading Spanish American National Anthems: "Sonograms" of National Identity
}

\section{ROBERT NEUSTADT}

In Costa Rica it is not uncommon to hear men greet one another on the street with the question, "¿Cómo va la lucha"? (How goes the struggle?). ${ }^{1}$ The reply is always consistent: "tenaz" (tenacious). The expression derives from a lyric from the Costa Rican national anthem:

En la lucha tenaz, de fecunda labor que enrojece el hombre la faz
In the tenacious struggle, of fertile labor

That reddens man's face

This reference to the national anthem in everyday talk underscores the extent to which the Costa Rican himno nacional has penetrated the lives of Costa Ricans. The symbolism is not difficult to comprehend. A man engaged in the tenacious struggle of agricultural work epitomizes the official representation of an ideal Costa Rican. As an image of Costa Rican identity, the lucha tenaz has, in some ways, been adopted by the populace. Many Costa Ricans feel proud of their nation, in large part because of its singular army-free condition. At the same time, to ask about the struggle usually elicits a smile if not laughter. Though Costa Ricans tend to be patriotic, the non-idyllic reality of quotidian existence (combined with deep-seated governmental corruption) injects a twist of irony into the lucha. By laughing at the expression, Costa Ricans poke fun at the hyperbolic idealism of their national anthem. The parody also arises from a process of recontextualization. Making reference to the national anthem "on the streets" - the speaker uses this song, usually reserved for civic ceremonies, to underscore the gap between official discourse and everyday reality.

Because most of us have listened to the same national anthem since childhood, it is easy to forget that the majority of himnos nacionales came to exist through a number of different musical and textual versions. The modifications introduced from one version to another reflect the push and pull of political history. My contention is that analyzing the lyrical, musical, political, and historical development of national anthems offers insight into the negotiation of national identity. Reading the various versions and modifications to national anthems underscores the manner in which these songs reflect a specific political culture at a given time. National anthems demonstrate the discourse with which those in power attempt to impose their view of the nation. ${ }^{2}$ From a historical perspective, furthermore, analyzing the transitions between different textual and musical representations of nationhood underscores the fluid nature of national identity in and of itself.

\footnotetext{
Many thanks to my colleague Bruce Hungate, whose support helped to bring this long-simmering article to completion. Thanks also to NAU editor Eve Constance Paludan who handled the technical/editorial chore of preparing the manuscript.

${ }^{1}$ All translations to English are my own, unless otherwise noted.

${ }^{2}$ There is not a great deal published on this subject. For a general study of national anthems from Africa, Asia, Europe and the Americas as expressions of nationalism, see José Antonio Crespo's article, "Nacionalismo, historia e himnos nacionales" in Trayectorias 11 (Enero-Abril 2003): 57-75.
} 


\section{Spanish American National Anthems and Identity}

In this essay, I analyze the text, music, and historical development of representative Spanish American national anthems. Since it would not be feasible to devote sufficient space to eighteen different national anthems in one essay, I discuss trends that recur in many anthems and then primarily concentrate on the Chilean and Costa Rican himnos nacionales. I have chosen to highlight these two anthems because their juxtaposition represents a long historical trajectory that marks, in each case, national identities that change in distinct historical time periods. The Chilean and Costa Rican anthems, furthermore, have both developed through a number of different versions that illustrate the liquidity of national identity. The Chilean and Costa Rican anthems also provide us with significant contrasts with respect to imagery, content, thematics, and historical development. Whereas the South American country's anthem came into being relatively early in the independence of the Americas (1819), the Central American counterpart was one of the last anthems to be written (1852). The compositional order between the music and text differs as well in these two examples. The Chilean anthem first took form as a set of lyrics, followed later by its musical composition. The Costa Rican anthem, on the other hand, was first a musical composition for which a series of lyrics were later written.

Although the Chilean and Costa Rican anthems were both developed over time through a series of different versions, the effect of history on national anthems does not always produce a revised or new song. In some cases, when an anthem reaches a certain age, the original attains a quality of reverence precisely because of its longevity. Bolivia, Ecuador, Perú, and Cuba conserve their first anthems. In Bolivia, a procession carries the original sheet music (partitura) through the streets to the Palacio Legislativo (Legislative Palace) on National Anthem Day (November 18). This ritual imbues the document itself with the value of a sacred relic. The Ecuadorean anthem retains its original lyrics to this day, though some stanzas with vehement anti-Spanish lyrics are no longer sung. Although there have been attempts to revise the lyrics to Ecuador's anthem, none of these revisions has been officially recognized. In 1948, a government decree forbade changes to the first official Ecuadorean national anthem (written by poet Juan León Mer)—declaring it "intangible” (unchangeable). A measure of the anthem's importance can be seen in the fact that Ecuador officially celebrates "National Anthem Week" (la semana del himno nacional) from November 22-29 and "National Anthem Day," El día del himno nacional on November 26. Perú's original anthem is similarly intact, though it underwent a series of changes over time. The Peruvian anthem was selected in a contest in September 1821. The lyrics were changed in 1901 after another contest. In 1959, the song was given a new introduction and the order of several stanzas was changed. In 2005, the Peruvian government officially restored the national anthem to its original form. The Cuban anthem, which I'll discuss later as a counterpoint to the cases of Costa Rica and Chile, has never undergone modification. What has changed is the manner in which the enemy figures of the song are interpreted.

Whereas, the last revisions to most Spanish American anthems were made during the nineteenth century, changing political conditions continue to result in proposals to update national anthems all over the world. I conclude this essay, moving beyond the national territories of Spanish America, with a brief reflection on recent international controversies that resulted from attempts to change or adapt the national anthems of Spain and the United States. In Spain, the national anthem has no lyrics, and a polemical disagreement ensued when the Spanish Olympic Committee proposed adding lyrics to the anthem. A conflict in the United States arose with the creation of a Spanish-language version of the lyrics. These 
recent cases are illustrative because they demonstrate the manner in which national anthems continue to underscore political wedge issues even today.

\section{Early Themes: Spain and the American Difference}

It should come as no surprise that national anthems often provide views of a country's "discovery," founding or independence. The image of history represented is, of course, highly ideological. The national anthems of Colombia, Honduras, and Panama trace their respective national identity back to the heroism of Columbus. The Panamanian anthem describes the country as the fertile world of Columbus, "este mundo feraz de Colón." The Honduran anthem personifies Honduras as a beautiful virgin Indian, discovered by the brave admiral Columbus:

$\begin{array}{ll}\text { India virgen y hermosa dormida, } & \text { Virginal and beautiful sleeping Indian girl } \\ \text { de tus mares al canto sonoro, } & \text { From your seas to the sonorous song, } \\ \text { cuando echada en tus cuencas de oro } & \text { When lying in your golden basins } \\ \text { el audaz navegante te halló; } & \text { The daring navigator found you; }\end{array}$

According to the Honduran anthem, Columbus not only found this sleeping virgin, he consecrated her with his love:

$$
\begin{aligned}
& \text { y al mirar tu belleza extasiado } \\
& \text { al influjo ideal de tu encanto } \\
& \text { la orla azul de tu espléndido manto } \\
& \text { con su beso de amor consagró. }
\end{aligned}
$$

\author{
Ecstatic, upon looking at your beauty \\ To the rising tide of your enchantment \\ The blue decoration of your splendid robe \\ With his kiss of love he consecrated her.
}

America, in the Honduran anthem, embodies the raw natural beauty that Columbus discovered and converted. Columbus, accordingly, "civilized" Honduras, he transformed the indigenous past into the modern nation of Honduras.

In celebrating their American difference, some anthems glorify their pre-Colombian indigenous ancestors. This is an ironic and subtle negotiation of identity. Whereas indigenous populations were (and are) marginalized from the national imaginary and resources by Latin American governments, the ancient indigenous cultures are exoticized. In the original Argentine anthem, "Marcha patriótica" (1813), the ancient Inca are lauded in the second complete stanza:

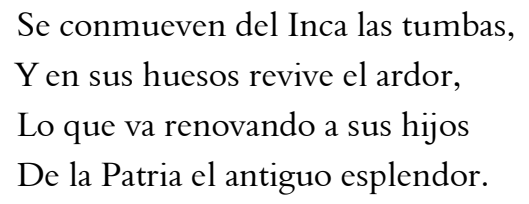

\author{
The tombs of the Inca shake \\ And in his bones the flame returns to life, \\ The Patria's ancient glory \\ is the source of new life for her sons.
}

The ancient Inca, in this anthem, represent the roots on which a uniquely American culture would be grafted.

The political exigencies of Independence movements required assertions of new separate identities. Early Spanish American national anthems, written around the time of independence, celebrate freedom, independence, and American difference. Many Spanish American countries defined their national identity in opposition to Spain. In celebrating the ancient glory of the Inca, the original Argentine anthem recognizes a specifically American, as opposed to a Spanish origin. Early versions of some national anthems bitterly refer to the Spaniards as vile invaders, "viles invasores" (Argentina, Chile), monsters, "monstruos" 
(Ecuador), and tyrants, "tiranos" (Argentina, Chile, Uruguay). Metaphors of breaking the chains of slavery (cadenas) appear ubiquitously in the anthems of Argentina, Colombia, Cuba, Dominican Republic, Guatemala, Perú, and Venezuela and related metaphors of breaking yokes (el yugo servil) and scepters (el cetro) appear in the anthems of Ecuador and Paraguay.

The details and histories narrated by national anthems vary from one country (or version) to another, but the purpose of the national anthem as a genre remains consistent. Singing the story of who "we" are, who we're not, and where we're from, national anthems explicitly represent national identity. National anthems are "musical flags," choral symbols that inaugurate official ceremonies to project an image of a country and its people. Of course as Benedict Anderson has shown, national identity is in many ways a fictional, imagined, discourse. The populace of any given country consists of a diverse section of differing racial, ethnic, social, political, economic, and cultural identities. The imaginary we evoked in a country's anthem folds the plethora of Others into the discursive mass of the Nation. As José Antonio Crespo writes, national anthems create imaginary unity: "El himno nacional . . cumple el propósito de crear o fortalecer una unidad esencialmente imaginaria" (A national anthem fulfills the purpose of creating or fortifying a unity that is essentially imaginary). Although many Others do not pertain to the mythic "we" of a nation, a performance of a national anthem often leads people to overlook the differences that set them apart. Overlooking the differences, people feel that they are part of the nation. How does this happen?

The dynamic of singing an anthem in a group constitutes an experience of community. "No matter how banal the words and mediocre the tunes," writes Anderson of national anthems, "there is in this singing an experience of simultaneity. At precisely such moments, people who are wholly unknown to each other utter the same verses to the same melody. The image: unisonance." ${ }^{4}$ By singing the same song together, citizens of diverse backgrounds form an imaginary community. Anderson points out that the knowledge of this community transcends the acoustic experience. People don't even have to hear one another, simply knowing that others are singing the same song at the same time creates a community. "Nothing connects us all but imagined sound," writes Anderson. ${ }^{5}$ In a sense, then, even the unisonance associated with the anthem is imagined.

If, as Anderson implies, the experience of unisonance can be imagined, there must be other factors, in addition to the effect of music on groups, that allow for national anthems to constitute communities. The process of modern education contributes to the construction of a national community through socialization and institutionalization. The act of singing (entonando) national anthems in school ceremonies, for example, aims to infuse a sense of national pride and identity. ${ }^{6}$ The national imaginary, then, takes shape from a state-initiated process of conditioning that begins in childhood. As I'll discuss in further detail in this essay, the concept of a national anthem in Costa Rica became part of the national program of education in the nineteenth century. Today, the himno nacional is sung daily in all public schools at 7:00 a.m. and is played on the radio at the same hour. The lyrics evoke an ideal message of national values, patriotism, work and peace, though this has not always been the case. The history of the

\footnotetext{
${ }^{3}$ José Antonio Crespo, "Nacionalismo, historia e himnos nacionales," Trayectorias 11 (Enero-Abril, 2003 ): 60.

${ }^{4}$ Benedict Anderson, Imagined Communities: Reflections on the Origin and Spread of Nationalism (London; New York: Verso, 1991), 145.

${ }^{5}$ Ibid.

${ }^{6}$ The fact that in Spanish the verb, entonar (to intone), describes the act of singing a national anthem, as opposed to the more general cantar (to sing), underscores the profound importance of national anthems within Spanish American culture.
} 
Costa Rican Himno nacional demonstrates the historical development of the very notion of a national anthem.

\section{The Costa Rican Himno Nacional}

Costa Rica did not have a national anthem in 1852, embarrassing the country's president at a time when the government was preparing for an important diplomatic visit from the British General Consul and a special Commissioner from the United States. ${ }^{7}$ The very point of the visit - to discuss a transoceanic canal through Nicaragua and the San Juan River (border with Costa Rica) - involves international borders. ${ }^{8}$ The Costa Rican National Anthem, in other words, arose in conjunction with an attempt to demarcate the limits of national territory. Costa Rican president Juan Rafael Mora Porras asked his military bandleader Manuel María Gutiérrez to compose the music for a national anthem. Allegedly, the composer first needed to find out "lo que era un "himno nacional," what was a national anthem." Gutiérrez then composed an instrumental military march (in anapestic rhythm) to receive the diplomatic mission on June 11, 1852. Although four different sets of lyrics were subsequently written for the Costa Rican national anthem, ${ }^{10}$ Gutiérrez's composition remains the official music. Whereas Gutiérrez's original himno was composed for an official ceremony, the purpose of the march was to flex national muscles in the diplomatic arena.

A survey of the different lyrics underscores historical changes in Costa Rica's declared national identity. The first set of lyrics, written by Colombian poet José Manuel Lleras in 1873, reiterate the bellicose nature of Gutiérrez's military march. The first stanza reads like many Spanish American national anthems that celebrate independence from Spain:

Costa Rica rompió las cadenas
que la ataban a extraño poder;
soltó al viento su propia bandera
i el imperio fundó de la lei.
Libertad proclamó entusiasmada,
libertad en el orden i el bien;
Del progreso ciñó la guirnalda
en su virgen i cándida sien! ${ }^{11}$

Costa Rica broke the chains
That tied her to a foreign power;
She released her own flag in the wind
And founded an Empire based on law.
The country proclaimed liberty
Liberty in order and good;
From progress she placed a garland
In her pure and virginal temple.

This first stanza shows the common figure of Costa Rica breaking the chains that tethered it to the foreign colonial power, Spain, and declaring itself free and sovereign - a country with its own flag invested in the goal of progress. The second stanza narrates Costa Rica's self-defense from subsequent foreign invasions,

\footnotetext{
${ }^{7}$ Amoretti cites historical documents of the visit of the British Consul Charles Wyke and the American Commissioner, Robert M. Walsh, on June 11, 1852.

${ }^{8}$ María Amoretti, Debajo del canto: un análisis del himno nacional de Costa Rica (San José, Costa Rica: Editorial de la Universidad de Costa Rica, 1987), 27-29.

${ }^{9}$ María Vargas Cullell, De las fanfarrias a las salas de concierto (San José, Costa Rica: Editorial de la Universidad de Costa Rica, 2004), 221.

${ }^{10}$ Different versions of the lyrics of the Costa Rican National anthem were written in 1873 by Colombian José Manuel Lleras, 1879 by Costa Rican Juan Garita, 1888 by Spaniard Juan Fernández Ferraz and 1903 by Costa Rican José María Zeledón.

${ }^{11}$ The lyrics of the four versions of the Costa Rican national anthem are published in Annex 3 of Vargas Cullell's De las fanfarrías a las salas de concierto, 281-2. My quotations of the Costa Rican anthems correspond to the versions cited by Vargas Cullell.
} 
specifically from the incursion in 1856 of confederate invader William Walker, who attempted to create a slave republic in Central America:

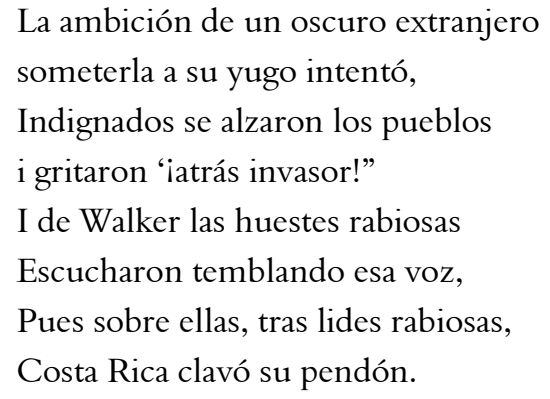

The ambition of a dark foreigner

Attempted to submit her to his yoke, Indignant, the people raised up And shouted 'Stay back invader!' And Walker's rabid followers Listened, trembling, to that voice, Upon them, after rabid struggles, Costa Rica nailed her banner.

The lyrics depict Walker's plan to enslave Costa Rica through the physical image of restricting her with a yoke $(y u g o)$. The fifth stanza again celebrates the historical battle when the Costa Rican armed forces rejected a subsequent invasion by Walker:

El cañón que en San Juan i San Jorge
hizo el polvo otro tiempo morder;
Al intruso bandido del Norte
su estampido prepara otra vez/
Si el clarín sanguinario resuena,
Costa Rica, con noble altivez,
'Guerra, Guerra!' dirá en sus cornetas,
'Ciudadanos, morir o vencer'!

The cannon that in San Juan and San Jorge Made the gunpowder bite again To the intruding bandit from the North Prepares its thunder again/ If the bloodthirsty bugle sounds again, Costa Rica, with noble pride, Will proclaim 'War, War!' with its cornets, 'Citizens, let us conquer or die'!

As we can see from these extracts, the first complete version of the Costa Rican national anthem pays homage-musically and poetically_to Costa Rica as a strong, independent military force. ${ }^{12}$ The bellicose aspect of the first national anthem of Costa Rica confirms that a country's image can change significantly over time and that this change can be observed through its national anthem. Contemporary Costa Rica-a country with no military that bases its national identity on a discourse of peace-defines itself very differently from the military image projected by its first two national anthems from 1852 and $1873 .{ }^{13}$

Let us skip ahead to the third set of lyrics for the Costa Rican national anthem, penned by Spaniard Juan Fernández Ferraz in 1888. This version again emphasizes the importance of defending la patria, though this time without including the historical mentions of Independence and the invasions of William Walker. Music historian María Clara Vargas Cullell argues that this was the first version of the Costa Rican national anthem to achieve significant diffusion amongst the populous. ${ }^{14}$ This is a clear case of the himno's insertion into the apparatus of a national institution of education. The Costa Rican government published the himno in a 2,000-copy edition of Cantares escolares (School Songs), edited by Fernández Ferraz and

\footnotetext{
${ }^{12}$ Many contemporary national anthems include formulaic threats to the effect that if they are invaded in the future that they will defend themselves to the death. See for example, the anthems of Bolivia, Chile, Cuba, Guatemala, Mexico, Uruguay and Venezuela.

${ }^{13}$ Costa Rica abolished its military in 1948 and specified the abolition of its armed forces in the constitution in 1949. On the history of the discourse of peace in Costa Rica, see the article, "Paz social e identidad nacional en Costa Rica durante los siglos XIX y XX by Iván Molina Jiménez.

${ }^{14}$ Vargas Cullell, 224.
} 
fellow Spaniard José Campabadal, for the express purpose of teaching the national anthem in schools. ${ }^{15}$ In 1894, Campabadal was given the post of National Music Inspector (Inspector de la Música). One of his responsibilities was to visit elementary and high schools in important Costa Rican cities on a monthly basis to ensure that the students sang their national anthem in tune. ${ }^{16}$

Fernández Ferraz's himno nacional is the first version that evokes the splendor of Costa Rica's natural beauty:

Desde el bosque sombrío al florido pensil cunda el eco potente, sublime ferviente, $\mathrm{y}$ al ara bendita, holocausto de amor las preseas llevemos de Gloria y honor.
From the somber forest to the hanging flowers The powerful echo reverberates, burning sublime, And the blessed alter, burnt offering of love

Let us carry the jewels of Glory and honor.

The sixth stanza again celebrates the resplendence of nature:

Nuestros bosques frondosos aliento nos dan, Con su dulce fragancia sutil;

Y del valle la verde llanura florida, Enérgico impulso de ardor juvenil.
Our lush forests give us breath, With their subtle sweet fragrance; And from the valley the green flowery plain, Energetic impulse of young ardor.

Although when cited in isolation these references to forests, valleys, sweet fragrances, and flowery plains appear to represent a tranquil image of Costa Rica, the song as a whole remains overwhelmingly bellicose. The first stanza sings of "bélica Lira" (bellicose lira), and the second calls for a fearless defense: "Nuestro hogar defendamos sin miedo a la lid" (Let's defend our home without fearing the battle). The third stanza evokes the national anthem itself as a thunderous war-chant:

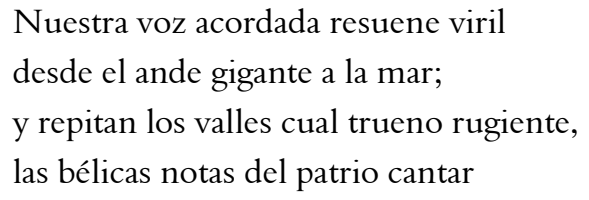

Our manly voice resonates in harmony From the gigantic mountain to the sea; And the valleys repeat the thunderous roar, The bellicose notes of the patriotic song.

Fernández Ferraz's anthem concludes with the final ultimatum of swearing the ultimate allegiance to the patria: "Juremos por ella vencer o morir" (Let's swear for her to conquer or to die).

Thematically, the thrust of this third version of Costa Rica's himno nacional sounds compatible with Manuel María Gutiérrez's military march. A slight musical issue inspired some revisions with respect to the music. The Spaniard, Campabadal, altered the original musical arrangement so that Fernández Ferraz's lyrics would meld rhythmically with the music. Essentially, Fernández Ferraz and Campabadal re-crafted the Costa Rican himno nacional - they wrote new lyrics (removing the references to Spain and William Walker), they celebrated Costa Rica's natural beauty, and they re-arranged the music so that it would correspond with this new image of Costa Rica. At the same time, they expanded the scope of the himno. The anthem that took shape as a musical flag took on an additional role, that of didactic and pedagogical text-a crucial tool in the musical and civic education of the nation.

The concept of a national anthem as part of the national program of education in Costa Rica has endured from the nineteenth century to the present day. The current lyrics, by José María Zeledón, were

\footnotetext{
${ }^{15}$ Ibid.

${ }^{16}$ Ibid., 224-225.
} 
chosen in a contest in 1903, perhaps in part because the lyrics are simpler, less intellectual, and thus easier to memorize than the prior version by Fernández Ferraz. ${ }^{17}$ In José María Zeledon's version, the bellicose images nearly disappear. Only three verses in the third stanza constitute a threat to potential invaders:

$\begin{array}{ll}\text { Cuando alguno pretenda tu gloria manchar } & \text { When someone tries to stain your glory } \\ \text { verás a tu pueblo, valiente y viril, } & \text { You will see your people, brave and virile, } \\ \text { la tosca herramienta en arma trocar. } & \text { Turn a primitive tool into a weapon. }\end{array}$

In this version, the Costa Rican hero is so deeply pacifist that if invaded he will need to improvise an armament from his farm tools. The central themes of the Costa Rican himno nacional clearly evoke the ideal values of work and peace. As Iván Molina Jiménez observes, Zeledón's anthem places the idea of using violence only in exceptional situations, violence in this anthem is a last resort of self-defense: "Sólo por excepción justifica trocar las herramientas por las armas" (Only an exception justifies changing tools for arms). The change to the discursive image projected by the Costa Rican himno is sharply revealed by contrasting the last verses of Fernández Ferraz's "Juremos por ella vencer o morir" (Let's pledge to conquer or die for the patria) to Zeledón's “viva siempre el trabajo y la paz” (long live work and peace). Ironically, Gutiérrez's military march music (re-worked by Carabadal) remains as the sonorous support for the lyrics.

Video example of the current national anthem of Costa Rica with lyrics: http://www.youtube.com/watch?v=kyQjSwIuSz4

This most recent version of the Costa Rican anthem might be conceived of as a palimpsestic time capsule - a hybrid song that simultaneously combines the music of a military march with lyrics, accrued over history, that represent the country as a bastion of work and peace.

\section{Chile's Himno Nacional: A Multi-National National Anthem}

The development of the Chilean anthem also meanders through a number of significant political and compositional turning points. Over the course of history we can see cyclical changes in Chilean identity that are expressed and modified through the national anthem. These historical negotiations underscore the irony involved in attempting to express and fix national identity through music.

Originally, Bernardo O'Higgins, the "Supreme Director" of independent Chile, conferred the task of writing the lyrics for a national anthem mid-way through 1819 to Argentine poet, Bernardo de Vera y Pintado. Given that the purpose of the Canción Nacional de Chile ${ }^{18}$ is to represent Chile, it resonates as slightly ironic that an Argentine poet penned the lyrics. Historically, nevertheless, there exist other cases in which national anthems have been written by composers or lyricists from other countries. Perhaps because

\footnotetext{
${ }^{17}$ Vargas Cullell, 227.

${ }^{18}$ The terms "Himno nacional" and "Canción nacional" are interchangeable in everyday usage in Chile. Bernardo de Vera's original 1819 song was entitled "Canción nacional de Chile." The current Constitution (written in 1980 and still in place) states in article 2 that the "Himno nacional de Chile" is an official symbol, an emblema nacional. Musicologically, the anthem corresponds more to a canción because of its estribillo (refrane), an element not traditionally present in himnos. (Personal e-mail correspondence, Cristián Guerra Rojas).
} 
of a lack of trained composers in the Americas, it was very common for foreigners to compose the music of Spanish American national anthems. ${ }^{19}$

What, then, is the relationship between the music and the lyrics? If the point of a Chilean national anthem is to represent Chile, what kind of interrelationship between the lyrics and the music would this imply? Theoretically, one might expect that the lyrics and music of a national anthem would function in parallel, constituting a cohesive unit of poetic and musical representation. History reveals, nevertheless, that the musical composition and the text of the lyrics can be quite divergent in terms of time, space, style and sentiment. The Costa Rican anthem, combining a military march from 1852 and a song celebrating peace from 1903, is a case in point. Since the music for the Chilean himno had yet to be composed, the first public performance of the newly-written Chilean national anthem (September 1819) was sung to the music from the national anthem of Argentina. With regards to the representation of nationhood this performance is both aesthetically and politically extraordinary. The original Chilean national anthem-the first formal effort to represent Chile via the combined symbolism of poetry and music-joined lyrics written by an Argentine with music that had been previously composed to represent a different country (Argentina) and a different set of lyrics. ${ }^{20}$

The Chilean anthem's musical history proves no less politically eclectic. Peruvian composer José Ravanete was asked to compose music for the Chilean anthem by O'Higgins's aide-de-camp, allegedly within eight days. Unable to compose his own melody on such short notice, Ravanete presented an adapted score based heavily on a Spanish song (known for opposing Napoleon's invasion). At the first public performance, a disgusted Vera y Pintado stood up and rejected the song for its association with the Spanish enemy. "Tiene visos de goda" (It's got Visigoth overtones) scoffed Vera. ${ }^{21}$

Subsequently, the Chilean, Manuel Robles, composed new music, though this version only lasted from 1820-1828.

\section{Audio example of Robles's "Canción nacional”: \\ http://www.memoriachilena.cl/temas/dest.asp?id=isizegersprimerhimno}

Due to complaints regarding the music, the Catalan musician Ramón Carnicer composed a new version of the music for the Chilean national anthem in 1828.

The nationality of the composers notwithstanding, these different musical scores grew from different parts of the nation. Musical compositions, like literary texts, do not arise from silence. They develop out of, or in reaction to, previous compositions. Though my last paragraph described the transition from Robles's to Carnicer's composition as a simple matter of quality, musicologist Cristián Guerra Rojas argues convincingly that a far more complex aesthetic, musicological, and political story lies embedded within the history. According to Guerra Rojas, Robles's song follows a Colonial era aesthetic,

\footnotetext{
${ }^{19}$ The music for the Colombian national anthem was composed by Italian, Oreste Sindici. The music for the Panamanian national anthem was composed by Spaniard, Santos Jorge. The music for the Argentinean national anthem was composed by Spaniard Blas Parera. Frenchman Antonio Neumane composed the music for the Ecuadoran national anthem. Italian Juan Alberle composed the music of the Salvadoran national anthem. Though the practice was less common, the lyrics of several anthems were written by foreign poets. The lyrics of Guatemala's national anthem were written by Cuban poet José Joaquín Palma (1897?), though Palma did live in Guatemala. The lyrics of the Paraguayan National Anthem were written by Uruguayan, Francisco Acuña de Figueroa (who also wrote the Uruguayan anthem).

${ }^{20}$ Cristián Guerra Rojas documents that three other Spanish American anthems (Venezuela, Uruguay, and Paraguay) were also originally sung to the melodies of other national anthems. He notes that the practice of singing lyrics to different previously composed melodies was also quite common in ecclesiastic music such as Catholic masses and Protestant hymns (7). ${ }^{21}$ Carlos Chubretovich A., Historia de la canción nacional de Chile (Santiago: Editorial La Noria, 1991), 33.
} 
based on relatively simple popular musical forms such as the villancico. ${ }^{22}$ Carnicer's version, on the other hand, manifests a more musically complex operatic composition that evokes influences of Rossini. ${ }^{23}$ Guerra Rojas goes so far as to propose that Robles and Carnicer represented opposing views of the nation: Robles represented the masses ("lo popular") while Carnicer was aligned, politically and aesthetically, with the elite.

If the music of the Chilean anthem came into being circuitously (from borrowing the Argentine anthem's music, to Ravanete's adaptation of a Spanish march, to Robles's and then Carnicer's respective compositions), the lyrics have undergone even more substantial historical revisions. Vera y Pintado's original poem invokes Chilean independence by distancing the country from Spain. The first stanza, for example, incites the Chilean citizen to rip the dagger from the Spanish tyrant and to break his neck:
Arrancad el puñal al tirano
Grab the dagger from the tyrant
Quebrantad ese cuello feroz
Break that ferocious neck

The end of the fourth stanza invites Chileans to take heart in the cadaver of a vile Spaniard rotting in a grave he sought in Chile, far away from his birthplace in Spain:
Ciudadanos mirad en el campo
Citizens look in the field
El cadáver del vil invasor...,
The cadaver of the vile invader...,
Que perezca ese cruel que el sepulcro
Let that cruel one perish who sought his tomb
Tan lejano a su cuna buscó
So far from his crib

The Spaniards are referred to repeatedly in negative terms, tiranos (tyrants, stanzas I, IV), vile despots (VIII) and monsters who carry with them an odious and servile character "monstruos que cargan consigo el carácter infame y servil" (stanza VII). Vera y Pintado's version of Chilean national identity, in other words, defines what it means to be Chilean in opposition to the base character of the Spanish oppressors. Ironically, it was a Spaniard, Carnicer, who ultimately set music to Argentine Vera y Pintado's diatribe against Spanish invaders. ${ }^{24}$ Carnicer, furthermore, never set foot in Chile. ${ }^{25}$

\footnotetext{
${ }^{22}$ Cristián Guerra Rojas, "Entre el olvido y la ruina: En torno a la Canción Nacional Chilena de Manuel Robles.” Resonancias. 20 (May, 2007), 13-14

${ }^{23}$ Guerra Rojas, 27.

${ }^{24}$ Though I refer to Carnicer as a "Spaniard" (as do many sources), it would be more accurate to call him Catalan. During the first half of the nineteenth century it is doubtful that someone from Catalonia would self-identify as "Español." This said, Carnicer was definitely from a region of the Spanish empire that had colonized the territory that subsequently achieved independence as the Republic of Chile.

The music to the Argentinean anthem was also written by a Catalan composer, Blas Parera, in 1812. According to legend, Blas Parera initially refused to write the music because of the song's visceral anti-Spanish bias. Allegedly, the Argentinean government gave him an offer that he couldn't refuse: he would compose the music or he would be executed. According to the story, Blas Parera "composed" the music for the Argentinean anthem in one night, transcribing the music from his previous composition, "Marcha patriótica," and then immediately leaving the country and ultimately returning to Spain (Bertolini, online). Carlos Vega refutes this version of history in his book, El himno nacional argentino: Creación, difusión, autores, texto, música. Vega goes to great lengths to document receipts for payment that Blas Parera received and dates the composer's return to Spain several years later (47-55).

${ }^{25}$ According to Robert Stevenson's entry in the Grove Music Online, the Chilean anthem is the only known Latin American anthem that was composed by a composer who never traveled to the Americas (online, 2003).
} 


\section{Subsequent Changes to the Chilean National Anthem}

In Chile the political tension with Spain had dissipated by $1846 .{ }^{26}$ Spaniards living and engaging in business felt uncomfortable with the hostile tone of the national anthem and requested that the President order a change to the lyrics. ${ }^{27}$ In 1847 the Minister of the Interior, Manuel Camilo Vidal, charged the poet Eusebio Lillo Robles with the task of re-writing the lyrics. ${ }^{28}$ Lillo's lyrics explicitly resolve the conflict with Spain as long-gone trouble from the past. The Spaniards—the first himno's tyrants and monsters—are now considered "brothers" in Lillo's first stanza:

Ha cesado la lucha sangrienta; ya es hermano el que ayer invasor
The bloody struggle has ceased

He who was an invader is now a brother

Lillo's new lyrics were subject to the approval of Andrés Bello, who approved all of them except for Lillo's chorus. It was decided to conserve the chorus from Vera y Pintado's original version. The Himno Nacional de Chile, then, constitutes a new image of Chilean national identity, chilenidad, via a collective/multinational/hybrid composition that combines the chorus written in 1819 by Argentine Bernardo de Vera y Pintado with verses written in 1848 by Chilean Eusebio Lillo and music composed in 1828 by the Catalan composer Ramón Carnicer. None of the three ever met one another.

Today the official anthem remains as described above, though only the chorus and fifth stanza are sung at official ceremonies. The official version is sung as follows:

Puro Chile, es tu cielo azulado,

Puras brisas te cruzan también,

Y tu campo de flores bordado

Es la copia feliz del Edén.

Majestuosa es la blanca montaña

Que te dio por baluarte el Señor, (bis)

$\mathrm{Y}$ ese mar que tranquilo te baña

Te promete futuro esplendor (bis, last two verses)

(stanza V, Lillo)

Coro:

Dulce Patria, recibe los votos

Con que Chile en tus aras juró

Que o la tumba serás de los libres

O el asilo contra la opresión. (Vera y Pintado)
Pure, Chile, is your blue sky;

Pure breezes flow across you as well.

And your flower-embroidered field

Is a happy copy of Eden.

Majestic is the (white) snow-capped mountain

That was given as a bastion by the Lord, (bis)

And the sea that quietly washes your shores

Promises you future splendor. (bis, last two verses)

(stanza V, Lillo)

Chorus:

Sweet fatherland, accept the vows

That were given by Chile at your altars:

Either you be the tomb of the free

Or the refuge against oppression. ${ }^{29}$

Audio example: http://www.youtube.com/watch?v=SvkVX99nBUc

\footnotetext{
${ }^{26}$ Spain officially recognized the independence of the Republic of Chile in 1845.

${ }^{27}$ Chubretovich, 38-43.

${ }^{28}$ The hostility towards Spaniards of the Argentinean National Anthem also became problematic over time. Rather than rewriting the lyrics, the Argentine government resolved the problem by deleting the majority of their anthem. A presidential decree (on March 30, 1900) officially limited the Argentine anthem to the first stanza with the last quartet and the chorus. This change, which cut the duration of the himno from 20 to 2 minutes, was carried out for the express purpose of respecting "la dignidad de milliares de españoles que comparten nuestra existencia" (the dignity of thousands of Spaniards who share our existence) (Mondolo, 12).

${ }^{29}$ English translation for the Chilean National Anthem from http://www.southamerica.cl/Chile/National_Anthem.htm
} 
The official sung-version of the Chilean national anthem primarily emphasizes purity ("Puro Chile" [pure Chile], "Puras brisas" [pure breezes]) and nature (the blue sky, breezes, flowers, mountains, and the ocean). The overall feeling expressed by Lillo's (fifth) stanza is one of peace, tranquility, and optimism. He invokes Chile as a copy of Eden, bathed by a tranquil sea. The final two verses of Vera y Pintado's chorus conserve some of the independista sentiment that Chile will remain free from oppression or they will die defending freedom. Nevertheless, since one only sings the chorus from Vera y Pintado's version, the overall message of the anthem became generally peaceful.

The tone of the anthem changed again during the Pinochet dictatorship when the military government instituted the practice of re-incorporating Lillo's third stanza, a celebration of soldiers, into the sung version:

Vuestros nombres, valientes soldados, Que habéis sido de Chile el sostén, nuestros pechos los llevan grabados; Los sabrán nuestros hijos también. Sean ellos el grito de muerte Que lancemos marchando a lidiar, Y sonando en la boca del fuerte Hagan siempre al tirano temblar.
Your names, valiant soldiers

Who have been the support of Chile

Our chests carry them engraved;

Our children will also know them.

Let your names be the shout of death

That we yell while marching to fight,

And pronouncing them in the mouth of the strong Let them always make the tyrant tremble.

In the context of dictatorial Chile, the convention of singing this stanza bore considerable symbolic weight.

Video example: Pinochet in 1989, singing the national anthem before a speech. The audience applauds when the stanza praising the military is sung:

http://www.youtube.com/watch?v=0IUFAKcbEns

By adding this stanza to civic ceremonies in schools, the dictatorship authorities obligated schoolchildren to sing a different version of the Chilean anthem-in other words, a new official version of Chilean identity - praising the bravery of the armed forces and invoking death for enemies. ${ }^{30}$ The stanza ends with a call-to-arms style command for the soldiers: "Make traitors tremble."

The point of adding this stanza was not subtle. The Pinochet government considered Salvador Allende, Chile's socialist president who was elected through democratic elections in 1970, to be a tyrant. Pinochet dramatized the coup of 1973 as a holy struggle between "good Chileans," and "bad" leftists, in this way legitimating, discursively, the military repression. Historically, then, the progression from one version of the Chilean National Anthem to another demarcates the oscillations of official Chilean national identity over time. Vera y Pintado's anthem identified Chilenos in contrast to vile and despicable Spaniards. Lillo penned a "softened" version with respect to Spaniards that Pinochet's military government later "re-hardened" as a threat to socialists. Reincorporating Lillo's formerly un-sung third stanza, the dictatorship used the himno to define its version of Chilean hero in opposition to leftists and the "tirano" Allende. The dictatorship imposed its version of national identity through military repression, discourse,

\footnotetext{
${ }^{30}$ Luis Puenzo's film, La historia oficial (1985), begins with a scene of schoolchildren singing the national anthem of Argentina at a ceremony in a school courtyard. The irony of their singing "Libertad, libertad, libertad" (Liberty, liberty, liberty) in the context of a repressive military dictatorship becomes more and more manifest as the film progresses.
} 
and music. ${ }^{31}$ Though it surely felt eternal to those forced to live within the confines of the dictatorship's image of national identity, this discourse was, and is, specific to a particular time in history.

Changing the official version of a national anthem has generational implications, since one learns to sing the national anthem in school. If we interpret the changes from version to version from too much of a macro perspective, nevertheless, we may fail to perceive the manner in which identity struggles take place within the oscillations of each cycle. In the time period following the dictatorship, Chile's democratic government again dropped Lillo's celebration of the military from official ceremonies. Whereas, this appears to be (and in many ways is) another historical oscillation, ongoing tensions make the transition to democracy more complicated, and less complete, than one may observe if simply noting the adoption of a new official version. Even today, Pinochet supporters and the military continue to sing Lillo's third stanza in protest. "Facebook" discussion boards call for reinstating the stanza: "Exigimos Incorporar la Estrofa de Nuestros Valientes Soldados a Nuestro Himno Nacional" (We Demand Incorporating the Stanza on Our Brave Soldiers in our National Anthem). ${ }^{33}$ The version of the anthem that a person sings in Chile today reveals his or her political orientation. ${ }^{34}$

\section{La Bayamesa: The National Anthem of Cuba}

Reading the changes that occur across history in different versions of national anthems underscores the manner in which identity is negotiated over time. Before concluding, I would like to briefly discuss the Cuban National Anthem because it can be seen as a counterpoint to the cases of Costa Rica and Chile. If ever a country changed its national identity, Cuba did so with the triumph of the Revolution of 1959. Interestingly, the revolutionary government felt no need to change the anthem. Cuba's national anthem, La Bayamesa (written in 1868 by Pedro [Perucho] Figueredo), sings praise of Cuban resistance to Spanish colonizers in the town of Bayamo. La Bayamesa was not written or composed as a national anthem per se, but rather began as a revolutionary song from the colony and was later adopted in 1902 as the national anthem of Cuba. The lyrics express Cuba's resolution to resist invaders militarily and, if necessary, to die while defending the patria (homeland):

\footnotetext{
${ }^{31}$ During the coup, the Chilean armed forces occupied radio and television stations and temporarily replaced normal programming with Nazi march music. Subsequently, the military government prohibited left-wing folk music, known as "New Song" (nueva canción chilena). For examples of how southern cone dictatorships combined music and torture, while others used music to resist repression, see my article, "Music as Memory and Torture: Sounds of Repression and Protest in Chile and Argentina." Chasqui: Revista de literatura latinoamericana, 33.1 (May 2004): 128-137.

${ }^{32}$ For a documented example of extant Pinochet supporters singing the Dictatorship's version in public as a protest, see the article from September 11, 2008, "Varios ministros de Bachelet acuden a homenaje a un ideólogo de Pinochet" in the online newspaper, elmundo.es Internacional (http://www.elmundo.es/elmundo/2008/1 1/09/internacional/1226254625.html). According to the article, when (left-wing) government ministers attended the inauguration of a monument for Jaime Guzmán (an ideologue of the Pinochet dictatorship), they were rebuked by pinochetistas who sang Lillo's eliminated third stanza in praise of Chilean soldiers.

${ }^{33}$ See the Facebook discussion board: http://www.facebook.com/topic.php?uid=67080095696\&topic=4981

${ }^{34}$ The conflict in regard to whether or not to sing Lillo's third stanza, between defenders of the dictatorship and its critics, is only the most recent struggle between two versions of the Chilean anthem. Carlos Chubretovich A. points out that the decision to replace Vera y Pintado's original lyrics with a new national anthem in 1848 also generated a polemic (38-43). Even Lillo, who wrote the new lyrics because he was asked to do so by the Minister of the Interior and Foreign Relations (Manuel Camilo Vial), resisted the change: "Una Canción Nacional no se debe cambiar y la de Vera era hermosa y representaba el período heroico de nuestra historia" ("A national anthem should not be changed and de Vera's song was beautiful and represented the heroic time in our history") (Chubretovich, 45). Cristián Rojas Guerra informs that the transition between Robles's (popularstyled) himno and Carnicer's elite-sounding composition aroused political disagreements as well.
} 
Al combate corred, bayameses, que la patria os contempla orgullosa; no temáis una muerte gloriosa que morir por la patria es vivir. En cadenas vivir es morir en oprobio y afrenta sumido; del clarín escuchad el sonido, ia las armas! iValientes corred!
To combat run, people from Bayamo

The homeland is watching you proudly;

Do not fear a glorious death

To die for the homeland is to live.

To live in chains is to die

In dishonor and outrage;

Listen to the sound of the bugle

Take arms! Run brave ones!

Audio/Video example from TV Cubana 2008:

http://www.youtube.com/watch?v=RFUs8DAiBtk

These lyrics, which were written as a call to arms in opposition to the Spanish colonizers, have served, and continue to serve, the contemporary revolutionary Cuban government. The lyrics remain the same, yet over time the real-world identity of the song's "enemy" has changed. Before and after Cuba won independence from Spain, the song referenced the Spanish colonizers as the implied enemy. During the Batista regime, government supporters continued to celebrate the historical importance of independence from Spain. At the same time, the anti-Batista revolutionaries identified with the notion that "living in chains" was tantamount to death. During the Revolution, then, La Bayamesa's call to arms took on the meaning of armed resistance to the Batista dictatorship. Subsequently, in the context of post-1959, Cuban exiles, the CIA, and American imperialists came to occupy the invader position that was formerly represented by Spaniards. ${ }^{35}$ Still today, those who vehemently oppose Cuba's socialist government, on the other hand, apply the image from the anthem-living en cadenas (in chains) - to life in contemporary Cuba. The manner in which La Bayamesa is interpreted-the identity of those associated with the "enemy" - modulates both over time and according to the ideology and political orientation of those interpreting the anthem.

\section{Contemporary International Anthem Controversies: Spain and the U.S.}

Although most of the different versions of Spanish American national anthems I have discussed were written in the nineteenth century, proposals to alter anthems continue to give resonance to controversial "wedge issues" even today. In Chile, the question of whether to sing or not to sing Lillo's stanza in homage to soldiers is a case of applying nineteenth-century lyrics to contemporary political conflict. Technically, neither side of the conflict is altering the lyrics, instead they are choosing whether or not to incorporate Lillo's third stanza.

A recent controversy arose in Spain over lyrics, in this case, due to the lack of lyrics. Spain is one of a minority of countries in the world whose national anthem does not have lyrics. In 2007 the President of

\footnotetext{
${ }^{35}$ The original Himno de la Bayamesa also contains vehement anti-Spanish lyrics:

No temáis; los feroces Iberos

son cobardes cual todo tirano

no resisten al brazo Cubano;

para siempre su imperio cayó.

Do not fear, the ferocious Iberians

They are cowards like any tyrant

Do not resist the Cuban arm;

Their empire has fallen forever.
}

Once Cuba became independent and the song became recognized as the official national anthem, stanzas such as this one were no longer sung. 
the Spanish National Olympic Committee, Alejandro Blanco, expressed dismay that Spanish athletes cannot sing their national anthem when receiving medals in the Olympics. ${ }^{36}$ The Spanish National Olympic Committee and the Sociedad General de Autores y Editores (General Society of Authors and Editors) convened a contest for citizens to write lyrics for the music of the Spanish national anthem, known as the "Marcha Real" (Royal March).

\section{Audio example "Marcha Real": http://www.spain-flag.eu/spanish-national-anthem.htm}

This proposal to choose lyrics for the anthem came about ostensibly to give Spanish athletes a song to sing when accepting awards at the Olympics. Politically, then, the proposal constituted a contemporary attempt to redesign Spain's musical flag. As a declaration of Spanish national identity, the song would not only be directed to unify the country (as was the case in the newly independent Spanish American countries, for example), but also to communicate the nature of Spanish national identity to athletes and fans from other countries and cultures, on the stage of the Olympics in the theatre of global television.

It had been planned to have Plácido Domingo sing the winning version, chosen out of 7,000 entries, at a ceremony on January 22, 2008. The committee then would attempt to gather a required 500,000 signatures to begin the legislative process of submitting the lyrics to Parliament to make the new lyrics legal and official. On January 11, 2008, however, the Spanish newspaper $A B C$ leaked that the Olympic Committee had chosen lyrics written by Paulino Cubero (an unemployed 52-year-old electrician), entitled "Viva España." The lyrics received such a negative reception by the public, that the committee canceled the award ceremony and withdrew their proposal after only five days.

A look at the history of the Spanish national anthem provides important context for the story. During the Franco dictatorship, Spaniards sang (or were forced to sing) unofficial lyrics to the Spanish National Anthem by right-wing intellectual José María Pemán. If we compare the proposed Cubero lyrics to those sung under Franco one notices marked parallels. Both begin with "Viva España" (Long live Spain). Whereas under Franco, they sang Pemán's "Gloria a la Patria” (Glory to the Fatherland), Cubero's version commands the citizen to love the Fatherland: "Ama a la Patria" (Love the Fatherland). The Franquista anthem concludes with a celebration of work and peace, "la vida nueva $y$ fuerte del trabajo $y$ paz" (the new and strong life of work and peace). Cubero's version ends with history giving justice, democracy, and peace, "justicia y grandeza / democracia y paz." Though in interviews it seems that Cubero does not feel great nostalgia for fascism, ${ }^{37}$ his version of the himno certainly used Pemán's poem as a starting point. One might argue that he celebrates moving on from fascism. From fascism's exaltation of "work and peace" Cubero's proposed lyrics progress to "democracy and peace." My point is not to debate the intentions of Cubero's lyrics, but rather to explore the issues raised by the controversy, which to a certain degree might have occurred, regardless of the lyrics chosen. Setting lyrics to the music immediately narrows the anthem's focus. The mere presence of lyrics determines and limits the more "open" expression of an anthem without words.

\footnotetext{
${ }^{36}$ See, "El Comité Olímpico Español encarga una letra para el himno nacional," http://www.elmundo.es/elmundodeporte/2007/06/02/masdeporte/1180750831.html

${ }^{37}$ For an interview with Paulino Cubero after his poem had been removed from consideration (January 22, 2008), see, “Así es Paulino Cubero: La desgracia de inventar el himno" in Enkidu, http://www.enkidumagazine.com/art/2008/200108/a_2001_017_a.htm
} 
Cubero's anthem was rejected by popular opinion, largely because of its intertextual allusions to unofficial lyrics sung under fascism, not to mention a generally perceived insipidness. The failure of the proposal left in place Spain's instrumental anthem, "La Marcha Real" (also known as the "Marcha Granadera"), a song dating from 1846 that originally rendered honor to the Spanish throne. Ironically, "La Marcha Real" was proclaimed the national anthem of Spain in 1939 during the dictatorship of Francisco Franco. ${ }^{38}$ Rejecting Cubero's lyrics, then, while retaining the music of "La Marcha Real," only goes so far in eliminating the echoes of fascism from the official image of Spanish national identity.

Another recent controversy arose in the United States in 2006, when the British music executive Adam Kidron released a Spanish-language version of the "Star Spangled Banner" entitled "Nuestro himno" (Our Anthem), sung by Puerto Ricans Olga Tañón and Carlos Ponce, Cuban-American "Pitbull" and Hatian Wyclef Jean on the album, Somos Americanos.

Audio example "Nuestro himno" from NPR site:

http://www.npr.org/templates/story/story.php?storyId=5369145

Kidron insists that he wrote the lyrics so that Spanish-speaking immigrants can sing the anthem of their adopted country to express their patriotism. 'We . . . view 'Nuestro himno' as a song that affords those immigrants that have not yet learned the English language the opportunity to fully understand the character of 'The Star-Spangled Banner,' the American flag and the ideals of freedom that they represent," explains Kidron in a New York Times article by John Holusha. ${ }^{39}$ Political conservatives, on the other hand, read the gesture as a desecration of "American" culture, history, tradition, and language. Charles Key, the great-great-grandson of the anthem's author, Francis Scott Key, vehemently denounced the idea of changing the "Star Spangled Banner:" "I think it's a despicable thing that someone is going into our society from another country and ... changing our national anthem." ${ }^{40}$ Note Key's two-pronged complaint: He abhors the change, which in his view is particularly despicable because its "authors" are Others who have come from a different country. The controversy reached the White House and led then-president George W. Bush to pronounce that the anthem sung in Spanish does not have "the same value as the anthem sung in English." According to Bush, immigrants in the U.S. should learn English: "I think people who want to be a citizen of this country ought to learn English and they ought to learn to sing the national anthem in English." ${ }^{42}$

Bush's comment, though ostensibly about language and the national anthem, reflects, on another level, the undercurrent of a contemporary political issue, illegal immigration. This becomes clearer if we contrast other alternative language versions of national anthems that pose no apparent threat. In Latin

\footnotetext{
${ }^{38}$ For a more detailed analysis of the controversy surrounding the Spanish national anthem, see my forthcoming article, "Whose himno is it? The Spanish National Anthem and the Communication of National Identity" in Connections 6: European Studies Annual Review.

${ }^{39}$ See "Bush says that anthem should be in English" by John Holusha (April 28, 2006), http://www.nytimes.com/2006/04/28/us/28cnd-anthem.html. Kidron further explains the patriotic impetus to "Nuestro himno" in an article by Joanna Walters: "I want the anthem to be more easily understood by Spanish-speakers and it is a mark of solidarity by Latin immigrants that they are prepared to share in this America" (http://www.guardian.co.uk/world/2006/apr/30/usa.joannawalters).

${ }^{40}$ See, “Spanish 'Star Spangled Banner'-Touting the American Dream or Offensive Rewrite” by Jim Avila (April 27, 2006), http://www.abcnews.go.com/WNT/story?id=1898460.

${ }^{41}$ John Holusha, "Bush Says Anthem Should Be in English," New York Times (April 28, 2006). http://www.nytimes.com/2006/04/28/us/28cnd-anthem.html

42 “Nuestro Himno's Foes Say U.S. Song should be in English” by Martin Miller in the Los Angeles Times (April 29, 2006), http://articles.latimes.com/2006/apr/29/entertainment/et-anthem29.
} 
America, indigenous-language versions of national anthems are not only tolerated, they are official staterecognized versions in Bolivia (Aymará, Quechua), Perú (Quechua), Ecuador (Quichua and Shuar) and Paraguay (Guaraní). ${ }^{43}$ Even in the United States, some Native American tribes, the Navajo and Cherokee, for example, have native-language versions of the "Star Spangled Banner," yet no one has criticized these translations. Analyzing the conflict over "Nuestro himno" reveals that the real issue is not language but rather the struggle over immigration politics. The Spanish lyrics, as a manifestation of the expansion of Latino culture and political power, is perceived as an invasion that threatens the integrity of the US's national image. In rejecting Spanish-language lyrics to the national anthem, the ultra-traditional faction of the U.S. power structure rejects an effort to include the Spanish-speaking Other as a part of "We the People."

\section{Conclusion}

Drafting a new national anthem, whether new music, lyrics or both, constitutes an effort to create and project a revised image of the nation. The fluctuations between the musical and textual versions of anthems, as well as changes in the ways that songs are received and interpreted, signal the role of national anthems in the construction of identity as well as the liquid, ever-changing characteristic of national identity in and of itself. The historical development of the Costa Rican and Chilean anthems, as we have seen, reveals the push and pull of the negotiation of national identities. These identities, like the national anthems that project and help constitute them, are notably hybrid. The current Costa Rican anthem combines the music of a military march with lyrics that celebrate the peacefulness of a country with no military. The national anthem of Chile is, paradoxically, multinational, combining a chorus by an Argentine with lyrics by a Chilean and music by a Spaniard. Even today the lyrics sung can still vary, depending on one's opinion of the Pinochet dictatorship.

From the music to the lyrics, los himnos nacionales developed, and continue to develop, changing with, and according to, shifting images of national identity. The proposal in Spain for (new) lyrics was rejected because of the manner in which the proposed lyrics resonated with words that were sung under fascism. Spaniards rejected, in other words, a historical image of national identity as did Chileans when the transitional government removed the stanza celebrating soldiers' valor from the sung version of the national anthem. The dispute over "Nuestro himno," a Spanish-language version of the "Star Spangled Banner," reveals the tensions associated with the incorporation of Latin American immigrants within the US body politic. As Latino and Spanish-speaking communities expand politically and culturally in the US, their place in this image becomes increasingly contested. Such recent controversies illustrate that the struggle to shape the moving image of a nation through song is not merely music of the past. The study of national anthems from a historical perspective provides images of the development of national identity. Reading national anthems, whether transitions between different versions of historical anthems or present day conflicts surrounding them, reveals images of identity in formation- "sonograms" of national development.

\footnotetext{
${ }^{43}$ In July of 2008, Ecuador removed Quichua as an official language from the new constitution (Carta Magna), though indigenous-language versions of the anthem in Quichua and Shuar exist.
} 


\section{References}

Amoretti, María. Debajo del canto: un análisis del himno nacional de Costa Rica. San José, Costa Rica: Editorial de la Universidad de Costa Rica, 1987.

Anderson, Benedict. Imagined Communities: Reflections on the Origin and Spread of Nationalism. London; New York: Verso, 1991.

Avila, Jim. "Spanish 'Star Spangled Banner'-Touting the American Dream or Offensive Rewrite." $A B C$ News (April 27, 2006), http://www.abcnews.go.com/WNT/story?id=1898460

Bertolini, Ana María. "La accidentada y curiosa historia del himno." Telam: Agencia de Noticias de la República Argentina (May 11, 2007). Accessed online, September, 2009: http://www.telam.com.ar/ vernota.php?tipo $=\mathrm{N} \& \mathrm{ridPub}=61877 \& \mathrm{id}=148946 \& \mathrm{dis}=1 \& \mathrm{sec}=1$

Chubretovich A., Carlos. Historia de la canción nacional de Chile. Santiago: Editorial La Noria, 1991.

Crespo, José Antonio. "Nacionalismo, historia e himnos nacionales.” Trayectorias. 11 (Enero-Abril, 2003): $57-75$.

Cubero, Paulino. "Así es Paulino Cubero: La desgracia de inventar el himno.” Enkidu (January 22, 2008). Interviewer, Aníbal Malvar. http://www.enkidumagazine.com/art/2008/200108/a_2001_017_a.htm

"El Comité Olímpico Español encarga una letra para el himno nacional.” El mundo. (June 2, 2007). http://www.elmundo.es/elmundodeporte/2007/06/02/masdeporte/1180750831.html

Guerra Rojas, Cristián. "Entre el olvido y la ruina: En torno a la Canción Nacional Chilena de Manuel Robles.” Resonancias. 20 (May, 2007).

Haro Tecglen, Eduardo. "El himno de Riego." El país. December 1, 2003. http://www.elpais.com/articulo/Pantallas/Himno/Riego/elpepirtv/20031201elpepirtv_5/Tes

Holusha, John. "Bush Says Anthem Should Be in English." New York Times (April 28, 2006). http://www.nytimes.com/2006/04/28/us/28cnd-anthem.html

Kidron, Adam. "Nuestro himno.” Somos Americanos. CD, Urban Box Office, 2006.

Lillo Robles, Eusebio. "Himno nacional de Chile.” (1847)

Lo que se canta en Costa Rica: Canciones escolares, de colegios y populares / Himnos de la América latina $12^{\text {th }}$ edition. Ed. J. Daniel Zúñiga Zeledón. San José de Costa Rica: Librería Universal, n.d..

López y Planes, Vicente. "Marcha patriótica” (Himno nacional argentino). La lira argentina. Buenos Aires: Biblioteca de Mayo, Senado de la Nación, 1960. Accessed online: http://www.biblioteca.clarin.com/pbda/poesia/himno/himno.htm

Miller, Martin. “Nuestro Himno’ Foes Say U.S. Song Should be in English.” Los Angeles Times (April 29, 2006), http://articles.latimes.com/2006/apr/29/entertainment/et-anthem29 
Molina Jiménez, Iván. "Paz social e identidad nacional en Costa Rica durante los siglos XIX y XX". Istmo: Revista virtual de estudios literarios y culturales centroamericanos 11(Julio-Diciembre, 2005). Online: http://collaborations.denison.edu/istmo/n11/proyectos/paz.html

Mondolo, Ana María. "Siglo XX: Decretos, resoluciones y leyes en torno al himno." In El himno nacional argentino: Creación, difusión, autores, texto, música by Carlos Vega. Buenos Aires: Educa, 2005, p. 119146.

Stevenson, Robert. "Ramón Carnicer." Grove Music Online. Online: http://www.oxfordmusiconline.com/ subscriber/article/grove/music/04971

Vargas Cullell, María. De las fanfarrias a las salas de concierto. San José, Costa Rica: Editorial de la Universidad de Costa Rica, 2004.

Vega, Carlos. El himno nacional argentino: Creación, difusión, autores, texto, música. Buenos Aires: Educa, 2005.

Vera y Pintado, Bernardo de. "Canción nacional de Chile." (1819).

Walters, Joanna. "Come Sing Along Señor Bush.” The Observer. (April 30, 2006). http://www.guardian.co.uk/world/2006/apr/30/usa.joannawalters 